\title{
Mycoplasma amphoriforme sp. nov., isolated from a patient with chronic bronchopneumonia
}

\author{
Correspondence \\ D. G. Pitcher \\ dave.pitcher2@btopenworld.com
}

\author{
D. G. Pitcher, \\ D. Windsor, ${ }^{2}$ \\ H. Windsor, ${ }^{2}$ J. M. Bradbury, ${ }^{3}$ \\ C. Yavari, \\ J. S. Jensen, ${ }^{4}$ \\ C. Ling ${ }^{5}$ and \\ D. Webster ${ }^{6}$
}

\begin{abstract}
${ }^{1}$ Respiratory and Systemic Infection Laboratory, Health Protection Agency, Specialist and Reference Microbiology Division, 61 Colindale Avenue, London NW9 5HT, UK

${ }^{2}$ Mycoplasma Experience Ltd, 1 Norbury Road, Reigate, Surrey RH2 9BY, UK

${ }^{3}$ Department of Veterinary Pathology, University of Liverpool, Leahurst, Neston, South Wirral CH64 7TE, UK

${ }^{4}$ Staten Serum Institut, Mycoplasma Laboratory, Artillerivej 5, Copenhagen DK-2300, Denmark

${ }^{5,6}$ Department of Microbiology ${ }^{5}$ and Department of Clinical Immunology ${ }^{6}$, Royal Free Hospital, Pond Street, London NW3 20G, UK
\end{abstract}

During a screening programme of immunodeficient patients, a novel mycoplasma strain (designated $\mathrm{A} 39^{\mathrm{T}}$ ) was isolated in high density on several occasions from the sputum of a patient with chronic bronchitis. There was reasonable evidence that this organism was responsible for the patient's symptoms (Webster et al., 2003). Subsequently, similar isolates were cultured from three other patients with bronchial symptoms.

Abbreviation: ITS, internally transcribed spacer.

The GenBank/EMBL/DDBJ accession numbers for the 16S rRNA gene and internally transcribed spacer sequences are AY531655 and AY531657, respectively, for strain $\mathrm{A}^{\mathrm{T}} 9^{\mathrm{T}}$ and $\mathrm{AY} 531656$ and AY531658, respectively, for strain M5572.

Details of the antisera used for the serological reactions and figures showing the colonial appearance and electron micrographs of cells of Mycoplasma amphoriforme $\mathrm{A}^{3}{ }^{\top}$, SDS-PAGE separation of proteins of Mycoplasma species, agarose gel separation of ITS and M. amphoriforme-specific 16S rRNA gene sequence amplicons, and PFGE of strain $\mathrm{A}_{39^{\top}}$ and Mycoplasma pneumoniae M129 are available as supplementary material in IJSEM Online.
Primary isolation of strains $\mathrm{A} 39^{\mathrm{T}}, \mathrm{A} 55$ and $\mathrm{A} 84$ was made in ME broth and agar medium (Hannan et al., 1997) at the Mycoplasma Experience Laboratory, Reigate, UK. Strain M5572 (=ATCC BAA-993) was isolated from the sputum of a patient with bronchitis on modified Friis medium, as used for the isolation of Mycoplasma genitalium (Jensen et al., 1996), at the Staten Serum Institute, Copenhagen, Denmark.

Growth on modified Hayflicks medium (Freundt, 1983) and SP4 medium (Tully, 1995) was also tested. Agar cultures were incubated at $37^{\circ} \mathrm{C}$ in gas jars $\left(95 \% \mathrm{~N}_{2}, 5 \% \mathrm{CO}_{2}\right)$ or with CampyGen gas packs $\left(8 \% \mathrm{CO}_{2}, 9 \% \mathrm{O}_{2}\right.$; Oxoid). Strains grew aerobically, but anaerobic growth was more rapid.

The organism was fastidious; it did not grow on modified Hayflicks medium. Growth was poor on conventional SP4 media, but better growth was obtained on SP4 containing $20 \%$ porcine serum instead of fetal bovine serum. The best growth was obtained on ME medium. On all media, 
approximately 7-14 days incubation was required before growth was detected.

Colonies on agar media lacked the characteristic 'fried egg' appearance of most mycoplasmas. The colonies were small $(<1 \mathrm{~mm})$, translucent and convex, with a glistening 'ground glass' appearance and lacking a central spot (Supplementary Fig. S1 in IJSEM Online). It is possible that the colonial appearance could be confused on occasion with that of other species from the human respiratory tract, as colonies of some freshly isolated cultures of Mycoplasma pneumoniae and M. genitalium have been reported as not having a central spot. The apparently related species Mycoplasma testudinis (from tortoise cloaca), Mycoplasma alvi (from bovine rumen) and Mycoplasma pirum (from laboratory cell lines) are described as having colonies typical of mycoplasmas (Hill, 1985; Gourlay et al., 1977; Del Giudice et al., 1985).

To ensure purity, strain $\mathrm{A} 39^{\mathrm{T}}$ was cultured in broth that was filtered through a $0 \cdot 2 \mu \mathrm{m}$ filter, cloned and passaged three times by colony isolation on agar medium.

The optimum growth temperature was $37^{\circ} \mathrm{C}$; growth did not occur at 30 or $40^{\circ} \mathrm{C}$ within 14 days.

For transmission electron microscopy studies, cells of strain $\mathrm{A} 39^{\mathrm{T}}$ were pelleted from a $100 \mathrm{ml}$ mid-exponential phase broth culture, fixed in buffered glyceraldehyde, post-fixed in osmium tetroxide, dehydrated in graded alcohols and embedded in Lemix epoxy resin and sectioned.

Electron micrographs (EMs) of ultrathin sections revealed 'flask-shaped' cells approximately $0.5 \mu \mathrm{m}$ in length with a trilaminar cell membrane, similar to $M$. pneumoniae, $M$. genitalium and M. pirum. Cells of strain $\mathrm{A} 39^{\mathrm{T}}$ differed from those of these species, however, in containing dense granules (Supplementary Fig. S2 in IJSEM Online). Although the nature of the granules could not be ascertained, they did not appear to be artefacts introduced by the EM processing, as cells of M. pneumoniae $\mathrm{FH}^{\mathrm{T}}$ that were treated identically did not show granules. The cells did not appear to possess electron-dense material in the tip (bleb) structure, as described for M. pneumoniae, M. genitalium and Mycoplasma gallisepticum.

It has been suggested (S. Razin, personal communication) that the granules in the cytoplasm of cells of strain $\mathrm{A} 39^{\mathrm{T}}$ resemble in their organization structures that were first reported in M. gallisepticum by Maniloff $(1971,1994)$, and interpreted as representing aggregations of polyribosomal helices. However, Korolev et al. (1994a, b) later reinterpreted them as representing tubular structures rather than ribosomes. At present the nature of these structures is not known.

The sterol requirement of strain $\mathrm{A} 39^{\mathrm{T}}$ was determined indirectly using the digitonin disc method (Poveda, 1998) and, directly, by measuring the growth response to cholesterol in broth using the method of Razin \& Tully (1970), except that a final inoculum of $7 \cdot 5 \%(\mathrm{v} / \mathrm{v})$ was used instead of $3 \%$. Strain $\mathrm{A} 39^{\mathrm{T}}$ required sterol for growth. It hydrolysed glucose, but not arginine, and reduced tetrazolium, but did not possess urease or phosphatase activity. Film and spot were not evident (Aluotto et al., 1970). On the basis of biochemical activity alone, strain $\mathrm{A} 39^{\mathrm{T}}$ could not be distinguished from M. pneumoniae or M. genitalium; however, M. pirum and M. alvi differ in hydrolysing arginine (Del Giudice et al., 1985; Gourlay et al., 1977) and M. testudinis in not reducing tetrazolium (Hill, 1985).

Haemadsorption of cells of strain $\mathrm{A} 39^{\mathrm{T}}$ to chicken, guinea pig and sheep erythrocytes and haemolysis of sheep erythrocytes were observed (Gardella \& Del Giudice, 1983). SDS-PAGE of whole-cell proteins was carried out on washed deposits from $20 \mathrm{ml}$ late-exponential phase broth cultures using the method of Laemmli (1970). Gels were stained with Coomassie blue. Visual examination of the gels revealed that the four novel isolates had very similar patterns that could be easily distinguished from those of other species known to infect humans, M. pneumoniae (three strains), M. genitalium (two strains), M. pirum (two strains), M. gallisepticum (one strain), M. alvi (one strain) and M. testudinis (one strain) (Supplementary Fig. S3 in IJSEM Online).

Serological reactions were performed using growth inhibition and immunofluorescence methods (Bradbury, 1998; Poveda \& Nicholas, 1998) with antisera to 110 Mycoplasma species (see supplementary material in IJSEM Online) against strain $\mathrm{A} 39^{\mathrm{T}}$ antigen. Rabbit polyclonal antiserum was prepared against strain $\mathrm{A}^{3} 9^{\mathrm{T}}$ (Senterfit, 1983) and reciprocal tests were carried out against cultures of other species where cross-reactions were observed. A few (13 growth inhibition and 10 immunofluorescence) weak reactions to the 110 mycoplasma antisera tested against $\mathrm{A} 39^{\mathrm{T}}$ cells were observed, but they were all confirmed as negative by reciprocal testing. Reciprocal tests with $\mathrm{A} 39^{\mathrm{T}}$ antiserum were also carried out with the type strains of members of the pneumoniae group (M. alvi, M. gallisepticum, M. genitalium, Mycoplasma imitans, M. pirum, M. pneumoniae and M. testudinis), with negative results. Isolates A55, A84 and M5572 gave positive reactions when tested by immunofluorescence with anti-A $39^{\mathrm{T}}$ rabbit antiserum, indicating a close antigenic relationship.

Purified DNA was prepared by extraction from centrifuged deposits of late-exponential phase $50 \mathrm{ml}$ broth cultures (Pitcher et al., 1989). Templates for PCR were prepared from centrifuged deposits from $5 \mathrm{ml}$ broth cultures with Chelex 100 (InstaGene kit; Bio-Rad).

The nucleotide sequences of both strands of the 16S rRNA gene of strains $\mathrm{A} 39^{\mathrm{T}}, \mathrm{A} 55, \mathrm{~A} 84$ and M5572 were determined using primers described by Johansson et al. (1998), but without solid-phase sequencing. Sequence reactions were carried out using a dye terminator cycle sequencing quickstart kit (Beckman Coulter) and the products were analysed on a CEQ 8000 genetic analysis system (Beckman Coulter).

In a BLAST search of the GenBank database (Altschul et al., 1990), the 16S rRNA gene sequence of strain $A 39^{\mathrm{T}}$ showed 


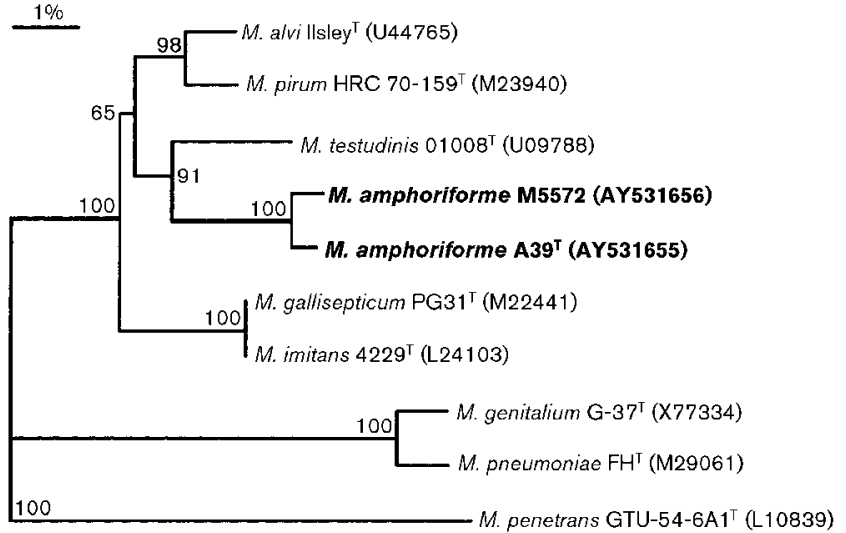

Fig. 1. Phylogenetic tree showing the 16S rRNA gene sequence neighbour-joining relationships between strains $A 39^{\top}$ and $M 5572$ and species of the $M$. pneumoniae group. $M$. penetrans GTU-54-6A1 ${ }^{\top}$ is included as an outlier. Bar, $1 \%$ sequence divergence.

greatest similarity to Mycoplasma species of the pneumoniae group. Sequences of Mycoplasma strains A39 ${ }^{\mathrm{T}}, \mathrm{M} 5572$ and the eight most closely related $16 \mathrm{~S}$ rRNA gene sequences of other species were subjected to phylogenetic analysis. Mycoplasma penetrans GTU-54-6A1 ${ }^{\mathrm{T}}$ was included as an outlier.

16S rRNA gene sequences of approximately 1476 bases from positions 34 to 1510 (Escherichia coli numbering; Brosius et al., 1978) were subjected to multiple alignment and phylogenetic trees were constructed using neighbourjoining and maximum-parsimony algorithms with the Kimura 2 adjustment provided in the Kodon version 1.0 software package (Applied Maths). Bootstrap resampling analysis for 500 replicates was performed to estimate the confidence of the tree topology. It is generally accepted that strains with $16 \mathrm{~S}$ rRNA gene sequence similarity of less than
$97 \%$ are members of different species (Stackebrandt \& Goebel, 1994). The 16S rRNA gene sequences of isolates A55, A84 and M5572 shared >98\% sequence similarity with strain $\mathrm{A} 39^{\mathrm{T}}$. However, the sequence similarity between M. pneumoniae $\mathrm{FH}^{\mathrm{T}}$ and $\mathrm{A} 39^{\mathrm{T}}$ or M5572 was only $93 \cdot 0 \%$. These strains appeared to be more closely related to $M$. testudinis $(96 \cdot 8 \%)$ and M. alvi $(96 \cdot 6 \%)$, based on the $16 \mathrm{~S}$ rRNA gene alone (Fig. 1), but not when other criteria were considered (Table 1).

The 16S-23S rRNA gene internally transcribed spacer (ITS) regions of all four strains were amplified using a 16S rRNA gene forward primer located at position 1353 and a 23S rRNA gene reverse primer at position 115 (Harasawa et al., 1993, 2004). The PCR product was sequenced in both directions using internal primers proposed by Harasawa et al. (1993, 2004). The length of the $16 \mathrm{~S}-23 \mathrm{~S}$ ITS sequence (368 bp) was greater than those of other Mycoplasma species in the clade, with the exception of $M$. gallisepticum (645 bp) and $M$. imitans (2488 bp, which contains a putative transposase gene; Harasawa et al., 2004). (Table 1 and Supplementary Fig. S4 in IJSEM Online). Pairwise alignments of the ITS sequences of $\mathrm{A}^{\mathrm{T}}{ }^{\mathrm{T}}$ (GenBank accession no. AY531657) and M5572 (GenBank accession no. AY531658) showed that these two strains had $98 \%$ sequence similarity, but the results of pairwise alignments of the ITS sequence of strain $A 39^{T}$ with those of other species related according to the $16 \mathrm{~S}$ rRNA gene sequence were $62 \%$ (M. testudinis $01008^{\mathrm{T}}$; GenBank accession no. AY785378), 58 \% (M. alvi Ilsley ${ }^{\mathrm{T}}$; AY779745), $56 \%$ (M. pirum HRC 70-159 ${ }^{\mathrm{T}}$; AY757364), $53 \%$ (M. pneumoniae $\mathrm{FH}^{\mathrm{T}}$; AF132740), $47 \%$ (M. genitalium $\mathrm{G}-37^{\mathrm{T}}$; D14526) and $38 \%$ (M. gallisepticum PG31 ${ }^{\mathrm{T}}$; AB098504).

The $\mathrm{G}+\mathrm{C}$ content of the DNA of strain $\mathrm{A} 39^{\mathrm{T}}$ was determined by using the fluorescence monitoring method described by Xu et al. (2000) with a LightCycler (Roche Diagnostics). Reference DNA from M. pneumoniae M129 was used for comparison $(\mathrm{G}+\mathrm{C}$ content $40 \mathrm{~mol} \%$;

Table 1. Properties that differentiate Mycoplasma species (type strains) of the pneumoniae group

Taxa: 1, M. amphoriforme sp. nov.; 2, M. pneumoniae; 3, M. genitalium; 4, M. pirum; 5, M. testudinis; 6, M. alvi; 7, M. gallisepticum. $\mathrm{V}$, Variable (reported to exhibit some atypical colonies on initial isolation); w, weak; NT, not tested. All species catabolize glucose.

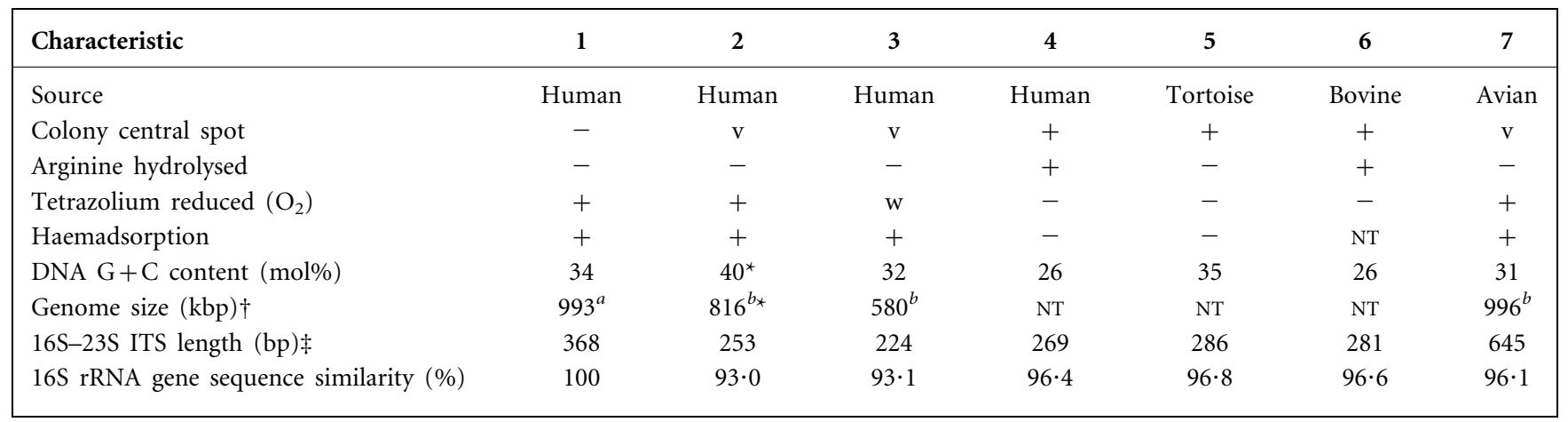

${ }^{\star}$ Reference DNA from M. pneumoniae M129 was used.

$\dagger$ Estimated from: $a$, restriction enzyme analysis; and b, genome sequences (Himmelreich et al., 1996; Fraser et al., 1995; Papazisi et al., 2003). ‡GenBank accession numbers AY531657, AF132740, D14526, AY757364, AY785378, AY779745 and AB098504, respectively. 
Himmelreich et al., 1996). The $\mathrm{G}+\mathrm{C}$ content of the DNA of strain $\mathrm{A} 39^{\mathrm{T}}$ was $34 \mathrm{~mol} \%$.

Genome size was estimated by using PFGE. DNA plugs were prepared from suspensions of strain $\mathrm{A} 39^{\mathrm{T}}$ in $\mathrm{TE}$ buffer (Neimark \& Carle, 1995). Restriction enzymes used were ApaI, BamHI, BglI, BssHI, KspI, NaeI, NarI, NheI, NotI, SacI, SalI, SfiI, SmaI, XbaI and XhoI.

PFGE was carried out using a CHEF-DR II apparatus (BioRad) with $1 \%$ PFGE-quality agarose gels in $0.5 \times \mathrm{TBE}$ running buffer at $200 \mathrm{~V}$ for $26 \mathrm{~h}$. Pulse times were 3-95 s. The mobility of fragments was compared to size standards consisting of a concatenated ladder of bacteriophage $\lambda$ DNA and yeast chromosome DNA size markers (Bio-Rad). The gel was visualized with ethidium bromide and photographed. Only two restriction enzymes, NotI and Sfil, cut the genomic DNA into useable fragments. Photographs of the gels were scanned and fragment lengths were estimated using BioNumerics software (Applied Maths).

PFGE of restriction fragments of the $\mathrm{A} 39^{\mathrm{T}}$ genome cut with Sfil revealed two fragments of 741 and $439 \mathrm{kbp}$, and two fragments of 1173 and $89 \mathrm{kbp}$ with NotI (Supplementary Fig. S5 in IJSEM Online). Therefore, the genome size of strain $A 39^{\mathrm{T}}$ was estimated to be $1180-1260 \mathrm{kbp}$. As a control, the same enzymes were used to cut the DNA of M. pneumoniae M129; fragments obtained were 554 and $441 \mathrm{kbp}$ (Sfil) and 847 and $164 \mathrm{kbp}$ (NotI) (Supplementary Fig. S5 in IJSEM Online), giving genome size estimations of between 995 and $1011 \mathrm{kbp}$. These values are high compared with the known genome size for M. pneumoniae M129 of 816394 bp determined from the complete genome sequence (Himmelreich et al. 1996). It has been observed that estimates based on the summation of restrictionfragment sizes may on occasion be higher than those estimated using other methods and might vary under different electrophoretic conditions (Neimark \& Lange, 1990). Therefore, each value for strain $A 39^{\mathrm{T}}$ was adjusted using the actual genome size of M. pneumoniae M129 as a standard, and sizes of $968 \mathrm{kbp}$ (Sfil) and $1018 \mathrm{kbp}$ (NotI) were obtained, giving a mean value of $993 \mathrm{kbp}$.

The $\mathrm{G}+\mathrm{C}$ content (34 mol\%) and genome size (993 kbp) of strain $\mathrm{A} 39^{\mathrm{T}}$ contrast with those of the related species M. pneumoniae $(40 \mathrm{~mol} \%$ and $816 \mathrm{kbp})$, M. genitalium (32 $\mathrm{mol} \%$ and $580 \mathrm{kbp}$ ) and M. gallisepticum ( $31 \mathrm{~mol} \%$ and $996 \mathrm{kbp})$. The $\mathrm{G}+\mathrm{C}$ contents of $M$. pirum, M. alvi and $M$. testudinis were 26, 26 and $35 \mathrm{~mol} \%$, respectively, but the genome sizes are not available (Himmelreich et al., 1996; Fraser et al., 1995; Papazisi et al., 2003; Del Giudice et al., 1985; Gourlay et al., 1977; Hill, 1985).

Specific PCRs for M. pneumoniae and M. genitalium were carried out (Cadieux et al., 1993), but were negative for all four isolates.

PCR based on unique primer sequences at positions 441 and 991 of the $16 \mathrm{~S}$ rRNA gene of strain $\mathrm{A} 39^{\mathrm{T}}$ was developed to identify other isolates belonging to the same putative species. The forward primer used was amph-F (5'AAGCTAGTAAAGGAAATGTTATT- $3^{\prime}$ ) and the reverse primer was amph-R (5'-TCGACTATATTTCTATAGTTTTG $\left.-3^{\prime}\right)$. Reaction mixtures $(50 \mu \mathrm{l})$ contained $50 \mathrm{mM} \mathrm{KCl}$, $2.5 \mathrm{mM} \mathrm{MgCl} 2,15 \mathrm{mM}$ Tris/HCl (pH 8.0), $200 \mu \mathrm{M}$ of each dNTP, 20 pmol of each primer and 1.5 U Taq DNA polymerase (Gibco-BRL). Broth culture deposits were extracted using an InstaGene kit (Bio-Rad). Samples $(10 \mu \mathrm{l})$ were added to the reaction mixtures. Following an initial denaturation step of $96^{\circ} \mathrm{C}$ for $3 \mathrm{~min}, 35$ cycles of $94{ }^{\circ} \mathrm{C}$ for $30 \mathrm{~s}, 56^{\circ} \mathrm{C}$ for $30 \mathrm{~s}$ and $72{ }^{\circ} \mathrm{C}$ for $40 \mathrm{~s}$ were carried out, followed by an extension step of $72^{\circ} \mathrm{C}$ for $5 \mathrm{~min}$. Reactions were performed using an MR DNA engine thermocycler (Genetic Research Ltd).

A 550 bp product was detected by electrophoresis in $1.5 \%$ agarose at $80 \mathrm{~V}$ for $2 \mathrm{~h}$. Gels were stained with ethidium bromide $\left(1 \mu \mathrm{g} \mathrm{l}^{-1}\right)$ for $30 \mathrm{~min}$ and photographed under UV illumination at $254 \mathrm{~nm}$. All four $\mathrm{A} 39^{\mathrm{T}}$-like isolates had this product, but other species in the M. pneumoniae group and other human mycoplasma species failed to amplify (Supplementary Fig. S6a, b in IJSEM Online).

\section{Conclusions}

When Tully (1993) reviewed the status of the mollicute flora of humans, 15 species were reported as having been isolated from human tissues on more than one occasion. Since then, no isolates have been described that could be confirmed as novel species. We believe that strain $\mathrm{A} 39^{\mathrm{T}}$ represents an undescribed member of the human microflora that might have implications for human health, because it exhibits metabolic synapomorphy with the pneumoniae group of mycoplasmas. Therefore, from a clinical diagnostic viewpoint, it is crucial that this strain can be distinguished from M. pneumoniae and other human mycoplasmas. To date, the acquisition of strains by patients and its role as a pathogen remain unclear. The species is fastidious and could easily be missed. Zoonotic infections with mycoplasmas have been reported in immunocompromised patients, but no one animal species has been linked to more than one patient. Therefore, it appears that this species is part of the human microflora, although it is not known at present whether the respiratory tract is its primary habitat.

At the time of writing, the minimal standards for descriptions of novel species of Mollicutes from 1995 apply (International Committee on Systematic Bacteriology Subcommittee on the Taxonomy of Mollicutes, 1995). We believe that this description of a novel species of Mycoplasma conforms to these standards.

\section{Description of Mycoplasma amphoriforme sp. nov.}

Amphoriforme (am.pho'ri.for'me. L. n. amphora -ae amphora; L. adj. suffix -formis -is -e like, of the shape of; 
N.L. neut. adj. amphoriforme having the form of an amphora, amphora-shaped).

Cells are flask-shaped with a trilaminar membrane and contain electron-dense granules. Aerobic or anaerobic growth occurs slowly on conventional mycoplasma media at the optimum temperature for growth of $37^{\circ} \mathrm{C}$. Colonies have a glistening 'ground glass' appearance and do not possess the typical 'fried egg' appearance common to most mycoplasmas. Requires serum or sterol for growth. Acid is produced from glucose. Arginine and urea are not hydrolysed. Tetrazolium is reduced. Phosphatase activity is negative. Cells adhere to chicken, guinea pig and sheep erythrocytes. Haemolytic on sheep erythrocytes. Serological tests show a lack of relatedness to the type strains of previously established Mycoplasma species.

The type strain is $\mathrm{A} 39^{\mathrm{T}}$ ( = NCTC $11740^{\mathrm{T}}=$ ATCC BAA$992^{\mathrm{T}}$ ). The 16S rRNA gene and the 16S-23S rRNA ITS sequences are unique and the SDS-PAGE whole-cell protein profiles are distinctive. All strains so far isolated were cultured from the human respiratory tract. The pathogenic status is not known. The $\mathrm{G}+\mathrm{C}$ content of the type strain is $34 \mathrm{~mol} \%$ and the genome size is $993 \mathrm{kbp}$.

\section{Acknowledgements}

We would like to thank the Electron Microscopy Unit at the Royal Free Hospital for their expert assistance.

\section{References}

Alluotto, B. B., Wittler, R. G., Williams, C. O. \& Faber, J. E. (1970). Standardized bacteriologic techniques for the characterization of Mycoplasma species. Int J Syst Bacteriol 20, 35-58.

Altschul, S. F., Gish, W., Miller, W., Myers, E. W. \& Lipman, D. J. (1990). Basic local alignment search tool. J Mol Biol 215, 403-410.

Bradbury, J. M. (1998). Identification of mycoplasmas by immunofluorescence. Methods Mol Biol 104, 119-125.

Brosius, J., Palmer, M. L., Kennedy, P. J. \& Noller, H. F. (1978). Complete nucleotide sequence of a $16 \mathrm{~S}$ ribosomal RNA gene from Escherichia coli. Proc Natl Acad Sci U S A 75, 4801-4805.

Cadieux, N., Lebel, P. \& Brousseau, R. (1993). Use of a triplex polymerase chain reaction for the detection and differentiation of Mycoplasma pneumoniae and Mycoplasma genitalium in the presence of human DNA. J Gen Microbiol 139, 2431-2437.

Del Giudice, R. A., Tully, J. G., Rose, D. L. \& Cole, R. M. (1985). Mycoplasma pirum sp. nov., a terminal structured mollicute from cell cultures. Int J Syst Bacteriol 35, 285-291.

Fraser, C. M., Gocayne, J. D., White, O. \& 26 other authors (1995). The minimal gene complement of Mycoplasma genitalium. Science 270, 397-403.

Freundt, E. A. (1983). Culture media for classic mycoplasmas. Methods Mycoplasmol 1, 127-135.

Gardella, R. S. \& Del Giudice, R. A. (1983). Hemagglutination, hemadsoption, and hemolysis. Methods Mycoplasmol 1, 379-384.

Gourlay, R. N., Wyld, S. G. \& Leach, R. H. (1977). Mycoplasma alvi, a new species from bovine intestinal and urogenital tracts. Int $J$ Syst Bacteriol 27, 86-96.
Hannan, P. C. T., Windsor, H. M. \& Ripley, P. H. (1997). In vitro susceptibilities of recent field isolates of Mycoplasma hyopneumoniae and Mycoplasma hyosynoviae to valnemulin (Econor), tiamulin and enrofloxacin and the in vitro development of resistance to certain antimicrobial agents in Mycoplasma hyopneumoniae. Res Vet Sci 63, 157-160.

Harasawa, R., Mizusawa, H., Nozawa, K., Nakagawa, T., Asada, K. \& Kato, I. (1993). Detection and tentative identification of dominant mycoplasma species in cell cultures by restriction analysis of the 16S23S rRNA intergenic spacer regions. Res Microbiol 144, 489-493.

Harasawa, R., Pitcher, D. G., Ramirez, A. S. \& Bradbury, J. M. (2004). A putative transposase gene in the 16S-23S rRNA intergenic spacer region of Mycoplasma imitans. Microbiology 150, 1023-1029.

Hill, A. C. (1985). Mycoplasma testudinis, a new species isolated from a tortoise. Int J Syst Bacteriol 35, 489-492.

Himmelreich, R., Hilbert, H., Plagens, H., Pirkl, E., Li, B. C. \& Herrmann, R. (1996). Complete sequence analysis of the genome of the bacterium Mycoplasma pneumoniae. Nucleic Acids Res 24, 4420-4449.

International Committee on Systematic Bacteriology Subcommittee on the Taxonomy of Mollicutes (1995). Revised minimum standards for description of new species of the class Mollicutes (division Tenericutes). Int J Syst Bacteriol 45, 605-612.

Jensen, J. S., Hansen, H. T. \& Lind, K. (1996). Isolation of Mycoplasma genitalium strains from the male urethra. J Clin Microbiol 34, 286-291.

Johansson, K.-E., Heldtander, M. \& Pettersson, B. (1998). Characterization of mycoplasmas by PCR and sequence analysis with 16S rDNA primers. Methods Mol Biol 104, 145-165.

Korolev, E. V., Nikonov, A. V., Brudnaya, M. S., Snigirevskaya, E. S., Sabinin, G. V., Komissarchik, Y. Yu., Ivanov, P. I. \& Borchsenius, S. N. (1994a). Tubular structures of Mycoplasma gallisepticum and their possible participation in cell motility. Microbiology 140, 671-681.

Korolev, E., Komissarchik, Ya. \& Borchsenius, S. (1994b). Мycoplasma helical structures - comment authors' reply. Microbiology 140, 2511-2512.

Laemmli, U. K. (1970). Cleavage of structural proteins during the assembly of the head of bacteriophage $\mathrm{T}_{4}$. Nature 227, 680-685.

Maniloff, J. (1971). Analysis of the helical ribosome structures of Mycoplasma gallisepticum. Proc Natl Acad Sci U S A 68, 43-47.

Maniloff, J. (1994). Microbiology Comment. Mycoplasma helical structures. Microbiology 140, 2511-2512.

Neimark, H. \& Carle, P. (1995). Mollicute chromosome size and characterization of chromosomes from uncultured mollicutes. In Molecular and Diagnostic Procedures in Mycoplasmology, vol. 1, pp. 119-131. Edited by S. Razin \& J. G. Tully. San Diego: Academic Press.

Neimark, H. C. \& Lange, C. S. (1990). Pulse-field electrophoresis indicates full-length Mycoplasma chromosomes range widely in size. Nucleic Acids Res 18, 5443-5448.

Papazisi, L., Gorton, T. S., Kutish, G. \& 7 other authors (2003). The complete genome sequence of the avian pathogen Mycoplasma

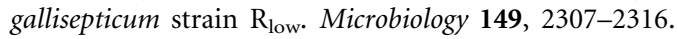

Pitcher, D. G., Saunders, N. A. \& Owen, R. J. (1989). Rapid extraction of bacterial genomic DNA with guanidium thiocyanate. Lett Appl Microbiol 8, 151-156.

Poveda, J. B. (1998). Biochemical characteristics in mycoplasma identification. Methods Mol Biol 104, 69-78.

Poveda, J. B. \& Nicholas, R. (1998). Serological identification of mycoplasmas by growth and metabolism inhibition tests. Methods Mol Biol 104, 105-112.

Razin, S. \& Tully, J. G. (1970). Cholesterol requirement of mycoplasmas. J Bacteriol 102, 306-310.

Senterfit, L. (1983). Preparation of antigens and antisera. Methods Mycoplasmol 1, 401-404. 
Stackebrandt, E. \& Goebel, B. M. (1994). Taxonomic note: a place for DNA-DNA reassociation and $16 \mathrm{~S}$ rRNA sequence analysis in the present species definition in bacteriology. Int J Syst Bacteriol 44, 846-849.

Tully, J. G. (1993). Current status of the mollicute flora of humans. Clin Infect Dis 17 (Suppl. 1), S2-S9.

Tully, J. G. (1995). Culture medium formulation for primary isolation and maintenance of mollicutes. In Molecular and Diagnostic Procedures in Mycoplasmology, vol. 1, pp. 119-131. Edited by S. Razin \& J. G. Tully. San Diego: Academic Press.
Webster, D., Windsor, H., Ling, C., Windsor, D. \& Pitcher, D. (2003). Chronic bronchitis in immunocompromised patients: association with a novel Mycoplasma species. Eur J Clin Microbiol Infect Dis 22, $530-534$.

Xu, H.-X., Kawamura, Y., Li, N., Zhao, L., Li, T.-M., Li, Z.-Y., Shu, S. \& Ezaki, T. (2000). A rapid method for determining the $\mathrm{G}+\mathrm{C}$ content of bacterial chromosomes by monitoring fluorescence intensity during DNA denaturation in a capillary tube. Int $J$ Syst Evol Microbiol 50, 1463-1469. 